\title{
Bone morphogenetic protein 15 and growth differentiation factor 9 co-operate to regulate granulosa cell function in ruminants
}

\author{
Kenneth P McNatty, Jennifer L Juengel, Karen L Reader, Stan Lun, Samu Myllymaa ${ }^{1}$, \\ Steve B Lawrence, Andrea Western, Mohamed F Meerasahib², David G Mottershead", \\ Nigel P Groome ${ }^{2}$, Olli Ritvos ${ }^{1}$ and Mika P E Laitinen ${ }^{1}$ \\ AgResearch, Wallaceville Animal Research Centre, Ward Street, PO Box 40063, Upper Hutt, New Zealand, \\ ${ }^{1}$ Program for Developmental and Reproductive Biology, Biomedicum Helsinki, and Department of Bacteriology \\ and Immunology, Haartman Institute, 00014 University of Helsinki, Helsinki, Finland and ${ }^{2}$ School of Biological \\ and Medical Sciences, Oxford Brookes University, Headington, Oxford, United Kingdom
}

Correspondence should be addressed to K P McNatty; Email: ken.mcnatty@agresearch.co.nz

\begin{abstract}
The oocyte-secreted polypeptide growth factors, growth differentiation factor 9 (GDF9) and bone morphogenetic protein 15 (BMP15, also known as GDF9B) have both been shown to be essential for ovarian follicular development and ovulation rate. In addition, it is known from both in vivo and in vitro studies that these factors co-operate in some manner. To date, most studies examining the in vitro effects of these growth factors have used the rodent model. However, the evidence suggests that these growth factors have somewhat different roles between rodents and ruminants. Therefore, the objectives of these studies were to examine the effects of GDF9 and BMP15, alone and together, on the functions of ovine and bovine granulosa cells under in vitro conditions. Ovine (o)BMP15 given together with murine (m)GDF9 or oGDF9 was more potent in stimulating ${ }^{3} \mathrm{H}$-thymidine incorporation by ovine granulosa cells compared with each growth factor alone. For bovine granulosa cells, there appeared to be little or no co-operativity between oBMP15 and oGDF9 as oBMP15 alone was as potent as any combination of the two growth factors in stimulating ${ }^{3} \mathrm{H}$-thymidine uptake. The species of origin of GDF9 affected the progesterone response in ovine granulosa cells with mGDF9 stimulating and oGDF9 inhibiting progesterone production. Ovine BMP15 alone had no effect on progesterone production by ovine granulosa cells and these growth factors did not appear to co-operate. FSH-stimulated progesterone production by bovine granulosa cells was most potently inhibited when oBMP15 and murine or ovine GDF9 were administered together. As was observed for progesterone, the species of origin of GDF9 affected inhibin production by ovine granulosa cells where mGDF9 inhibited while oGDF9 stimulated production. Murine GDF9 also inhibited inhibin production from bovine granulosa cells. For both ovine and bovine granulosa cells, BMP15 alone had no effect on inhibin production and there did not appear to be any co-operation between GDF9 and BMP15. These results indicate that the effects of BMP15 and GDF9 varied with respect to the species of origin of the growth factor. Moreover, the effects of GDF9 and BMP15 together were often co-operative and not always the same as those observed for these growth factors alone.
\end{abstract} Reproduction (2005) 129 481-487

\section{Introduction}

The oocyte-derived members of the transforming growth factor- $\beta$ superfamily, namely growth differentiation factor 9 (GDF9) and/or bone morphogenetic protein 15 (BMP15, also known as GDF9B), have been shown to be essential regulators of follicular development in rodents, sheep and humans (Elvin et al. 2000, McNatty et al. 2003, Di Pasquale et al. 2004, Shimasaki et al. 2004). In addition, both proteins have been shown to regulate ovulation rate in sheep (Davis et al. 1991, Galloway et al. 2000,
Hanrahan et al. 2004, Juengel et al. 2004). Although there is evidence of co-operativity between these closely-related growth factors with respect to follicular growth and ovulation rate (Yan et al. 2001, Hanrahan et al. 2004), the roles of GDF9 and BMP15 appear to differ between species. For example, while both mice (Dong et al. 1996) and sheep (Hanrahan et al. 2004) with inactivating mutations in GDF9 are infertile, with primary ovarian failure, mice lacking active BMP15 (Yan et al. 2001) have only minor defects in follicular growth whereas sheep 
homozygous for inactivating mutations in BMP15 are infertile with primary ovarian failure (Galloway et al. 2000, Hanrahan et al. 2004). In addition, while a role for both BMP15 and GDF9 in regulation of ovulation rate in sheep has been shown (Davis et al. 1991, Hanrahan et al. 2004, Juengel et al. 2004) no such role is apparent in mice (Dong et al. 1996, Yan et al. 2001). These observations could be related to differences in responses of granulosa cells to GDF9 and BMP15 or, potentially, to divergent affects of the growth factors from different species. We have recently shown that GDF9 and BMP15 co-operate in vitro to modulate functions of granulosa cells from rats (McNatty et al. 2005). However, little is known about the roles of these growth factors and their potential interactions in ruminants. Therefore, the objectives of the present studies were to examine the effects of ovine (o) GDF9 and oBMP15 alone and together on granulosa cell functions of sheep and cattle under in vitro conditions. Furthermore, as the effects of murine (m)GDF9 on granulosa cells of several species have been characterized, a comparison between the effects of oGDF9 and mGDF9 for each species of granulosa cells were undertaken.

\section{Materials and Methods}

The mGDF9, oGDF9 and oBMP15 constructs used for generating stably transfected cell lines has been described previously (Kaivo-Oja et al. 2003, McNatty et al. 2005). The recombinant protein was produced into serum-free harvesting medium (DMEM/Ham's F-12, 1:1) supplemented with L-glutamine and antibiotics $(100 \mathrm{U} / \mathrm{ml}$ penicillin and $100 \mu \mathrm{g} / \mathrm{ml}$ streptomycin), 0.01\% (w/v) BSA (Sigma, Auckland, NZ) and $100 \mu \mathrm{g} / \mathrm{ml}$ heparin (Sigma, Auckland, NZ). The amounts of GDF9 or BMP15 in conditioned media were determined by Western blotting as described previously (McNatty et al. 2005). The reference standards used to assess the concentrations of mammalian-derived GDF9 and BMP15 were E. coli produced oGDF9 and oBMP15. Although the concentrations of $1000-2000 \mathrm{ng} / \mathrm{ml}$ of GDF9 and $4-8 \mathrm{ng} / \mathrm{ml}$ of BMP15 were investigated in these studies, these differences are likely to be related, at least in part, to the binding affinities of the antibodies used to the $E$. coli and mammalian derived growth factors. Attempts at concentrating BMP15 in 293 media did not lead to increased biological activity.

\section{Granulosa cell collection}

Ovaries were collected from ewes and cows following slaughter at the local abattoir, transported back to the laboratory at ambient temperature, washed in a $3 \%$ bleach solution in PBS for $5 \mathrm{~min}$, rinsed twice in PBS and stored in Leibovitz L-15 media. Follicles, approximately 1-2 mm (ewes) or 1-4.5 mm (cows) in diameter, were dissected from the ovaries and stored in Leibovitz L-15 media until collection of the granulosa cells. Subsequently, the follicles were cut in half and the granulosa cells were removed using a wire loop. For both species, the oocytecumulus cell complexes, isolated oocytes and follicular debris were visualized using a dissecting microscope and most, if not all, were removed from the cells using a glass pipette. The granulosa cells were then recovered following centrifugation at $300 \mathrm{~g}$ for $5 \mathrm{~min}$ at room temperature after one wash in $5 \mathrm{ml}$ Leibovitz L-15 media.

\section{Culture of granulosa cells for determination of ${ }^{3} \mathrm{H}$-thymidine incorporation}

The cells were washed a further time in $5 \mathrm{ml}$ M199 (Earle's, Sigma) with $100 \mathrm{U} / \mathrm{ml}$ penicillin, $100 \mu \mathrm{g} / \mathrm{ml}$ streptomycin, $2 \mathrm{mM}$ GlutaMAX-1 (Invitrogen), $0.3 \mathrm{mg} / \mathrm{ml}$ polyvinyl alcohol (Sigma) and $0.23 \mathrm{mM}$ sodium pyruvate (Sigma) and resuspended using a syringe and needle in M199. Cell viability was determined using trypan blue exclusion. Granulosa cells (20000 viable cells in a total volume of $125 \mu \mathrm{l}$ per well) were cultured in M199 with varying amounts of conditioned media from control (untransfected), GDF9 expressing or BMP15 expressing $293 \mathrm{H}$ cells at $37^{\circ} \mathrm{C}$ in a $5 \% \mathrm{CO}_{2}$ incubator. After $18 \mathrm{~h}$ of culture, methyl- ${ }^{3} \mathrm{H}$-thymidine (Perkin Elmer, Boston, MA, USA; $20 \mathrm{Ci} / \mathrm{mmol}, 0.4 \mu \mathrm{Ci}$ per well) was added to each well and the culture continued for an additional $6 \mathrm{~h}$ after which the cells were harvested with a cell harvester onto a thin filter mat. Incorporation of ${ }^{3} \mathrm{H}$-thymidine was determined using a Wallac Trilux MicroBeta 1450 liquid scintillation counter (Biolab, Auckland, NZ). Treatments included 1000 or $2000 \mathrm{ng} / \mathrm{ml}$ of mGDF9 or oGDF9, 4 or $8 \mathrm{ng} / \mathrm{ml}$ of oBMP15, or a combination of $1000 \mathrm{ng} / \mathrm{ml}$ mGDF9 with $4 \mathrm{ng} / \mathrm{ml}$ oBMP15, or $1000 \mathrm{ng} / \mathrm{ml}$ oGDF9 with $4 \mathrm{ng} / \mathrm{ml}$ oBMP15. These concentrations of GDF9 and BMP15 were the maximum that could be tested within the volume limits of the bioassay based on the use of a maximum of $40 \%$ of conditioned media. In addition, the effects of diluting the oGDF9 (200, 100, 20 and $10 \mathrm{ng} / \mathrm{ml})$ while oBMP15 concentrations were held constant at $4 \mathrm{ng} / \mathrm{ml}$, and diluting the $\operatorname{OBMP15}(2,0.8,0.08$ and $0.04 \mathrm{ng} / \mathrm{ml}$ ) while oGDF9 concentrations were held constant at $1000 \mathrm{ng} / \mathrm{ml}$ were determined. All control wells were treated with an identical volume of conditioned media from untransfected $293 \mathrm{H}$ cells. For all assays, all treatments were applied at least in triplicate with a minimum of three independent pools (range 3-11) of granulosa cells being tested. Within an assay, individual values outside $30 \%$ of the mean value for the treatment were discarded. Points in which at least two of the replicates were not within $30 \%$ of each other were regarded as missing data.

\section{Culture of granulosa cells for determination of progesterone and inhibin production}

The cells were washed a further time in $5 \mathrm{ml}$ McCoys $5 \mathrm{a}$ media (Sigma) with $100 \mathrm{U} / \mathrm{ml}$ penicillin, $100 \mu \mathrm{g} / \mathrm{ml}$ streptomycin, $2 \mathrm{mM}$ GlutaMAX-1 and $0.1 \% \mathrm{BSA}$ and resuspended using a syringe and needle in McCoys 5 a media. 
Cell viability was determined using trypan blue exclusion. Granulosa cells (100000 viable ovine and 75000 viable bovine cells per well; $250 \mu$ l total volume) were cultured in McCoys 5 a media containing $5 \mathrm{ng} / \mathrm{ml}$ sodium selenite (Sigma), $10 \mathrm{ng} / \mathrm{ml}$ bovine insulin (Sigma), $5 \mu \mathrm{g} / \mathrm{ml}$ holotransferrin (Invitrogen), $30 \mathrm{ng} / \mathrm{ml}$ androstenedione (Sigma), $3 \mathrm{ng} / \mathrm{ml}$ ovine follicle-stimulating hormone $(\mathrm{oFSH}$; prepared in our laboratory, $1.4 \times$ USDA-oFSH-19-SIAFP RP2), 1 ng/ml IGF-1 (Long-R3, Gro-Pep, Sydney, Australia) with varying amounts of conditioned media from control (untransfected) GDF9 expressing and/or BMP15 expressing $293 \mathrm{H}$ cells. Cells were cultured at $37^{\circ} \mathrm{C}$ in a humidified incubator with a $5 \% \mathrm{CO}_{2}$ in air gas phase. Every $48 \mathrm{~h}$, $200 \mu \mathrm{l}$ of media was removed from each well and replaced with $200 \mu \mathrm{l}$ of warmed media that had been prepared at the start of the culture and stored at $4{ }^{\circ} \mathrm{C}$. Media samples from the last $48 \mathrm{~h}$ of treatment were collected on day 6 of treatment and frozen at $-20^{\circ} \mathrm{C}$ for later determination of progesterone and inhibin concentrations by RIA. Treatments included the addition of 1000 or $2000 \mathrm{ng} / \mathrm{ml}$ of mGDF9 or oGDF9, 4 or $8 \mathrm{ng} / \mathrm{ml}$ oBMP15 or the combination of $1000 \mathrm{ng} / \mathrm{ml} \mathrm{mGDF9}$ with $4 \mathrm{ng} / \mathrm{ml}$ oBMP15, or $1000 \mathrm{ng} / \mathrm{ml}$ oGDF9 with $4 \mathrm{ng} / \mathrm{ml}$ oBMP15. In addition, the effects of diluting oGDF9 (200, 100, 20 and $10 \mathrm{ng} / \mathrm{ml}$ ) while oBMP15 concentrations were held constant at $4 \mathrm{ng} / \mathrm{ml}$ or diluting oBMP15 (2, 0.8, 0.08 and $0.04 \mathrm{ng} / \mathrm{ml})$ while oGDF9 concentrations were held constant at $1000 \mathrm{ng} / \mathrm{ml}$ were determined in some instances. All treatments were applied at least in triplicate to a minimum of five independent pools (range 5-15) of granulosa cells for each species. Within an assay, individual values outside of $20 \%$ of the mean value for the treatment were discarded. Points in which at least two of the replicates were not within $20 \%$ of each other were regarded as missing data.

\section{Determination of progesterone and inhibin concentrations in media}

The concentrations of progesterone in media were determined by RIA as described previously (Asher 1990). The sensitivity of the assay ( $90 \%$ maximum binding) was $17 \mathrm{pg} / \mathrm{ml}$ and the intra- and inter-assay coefficients of variations, averaged for a standard pool sample at approximately $20 \%, 50 \%$ and $80 \%$ binding, were overall $7.8 \%$ and $7.5 \%$ respectively. No samples were below the sensitivity of the assay. The concentrations of inhibin were determined by RIA as previously described (McNatty et al. 1992). The antibody to inhibin detects $31 \mathrm{kDa}$ inhibin and the pro- $\alpha \mathrm{C}$ subunit (Robertson et al. 1989). The intra- and inter-assay coefficients of variations were $11.0 \%$ and $11.7 \%$ respectively. The sensitivity of the assay was $13 \mathrm{IU} / \mathrm{ml}$ bINH R-90/1 standard: no samples were below the sensitivity of the assay.

\section{Statistical analysis}

The differences between treatments and control were determined using the two-tailed paired $t$-test function in Microsoft Excel 2003. The control samples always contained an equivalent amount of untransfected $293 \mathrm{H}$ conditioned media as the treated samples. The values for ${ }^{3} \mathrm{H}$-thymidine incorporation and inhibin were transformed (natural $\log$ ) prior to analyses. Differences in responses between treatments were determined using the two-tailed $t$-test function in Microsoft Excel 2003 using the ratio to control values. For ease of presentation, all values have been converted to a ratio of the appropriate controls which were assigned a value of 1.00. The geometric means (and 95\% confidence limits) for ${ }^{3} \mathrm{H}$-thymidine incorporation into ovine and bovine granulosa cells treated with $293 \mathrm{H}$ control media were $122(88,169)$ and $848(563,1278)$ c.p.m./well respectively. The means \pm S.E.M. for progesterone production by ovine and bovine granulosa cells treated with $293 \mathrm{H}$ control media were $24 \pm 2$ and $66 \pm 6 \mathrm{ng} /$ well respectively. The geometric means (and 95\% confidence limits) for inhibin production by ovine and bovine granulosa cells treated with $293 \mathrm{H}$ control media were 178 (126, $250)$ and $83(60,115) \mathrm{IU} /$ well respectively.

\section{Results \\ ${ }^{3} \mathrm{H}$-thymidine incorporation}

Sheep

mGDF9 inhibited thymidine incorporation into ovine granulosa cells whereas oGDF9 on its own had no effect (Fig. 1). oBMP15 stimulated thymidine incorporation at the highest dose. The addition of either mGDF9 or oGDF9 with oBMP15 resulted in a significant stimulation of thymidine incorporation. This effect was in contrast to the suppression observed when mGDF9 was added alone, or the absence of a significant increase or decrease with either oGDF9 or oBMP15 alone at equivalent doses. When oGDF9 was serially diluted from $1000 \mathrm{ng} / \mathrm{ml}$ to $10 \mathrm{ng} / \mathrm{ml}$ in the presence of $4 \mathrm{ng} / \mathrm{ml}$ BMP15, the significant stimulatory effect on thymidine incorporation was maintained. However, when oGDF9 concentrations were held constant at $1000 \mathrm{ng} / \mathrm{ml}$ but oBMP15 was diluted from $4 \mathrm{ng} / \mathrm{ml}$ to $0.04 \mathrm{ng} / \mathrm{ml}$, the significant stimulation of thymidine incorporation was only observed when oBMP15 concentrations were $>2 \mathrm{ng} / \mathrm{ml}$ ( $n=6$ independent pools of granulosa cells, data not shown).

\section{Cow}

mGDF9 inhibited thymidine incorporation into bovine granulosa cells whereas oGDF9 on its own had no effect (Fig. 1). oBMP15 stimulated thymidine incorporation at both doses used and the addition of either murine or ovine GDF9 to oBMP15 stimulated thymidine incorporation, but the overall values obtained were similar to those for equivalent concentrations of oBMP15 alone (Fig. 1). When oGDF9 was serially diluted from $1000 \mathrm{ng} / \mathrm{ml}$ to $10 \mathrm{ng} / \mathrm{ml}$ in the presence of $4 \mathrm{ng} / \mathrm{ml} \mathrm{BMP15}$, the significant stimulatory effect was maintained at all dilutions. When 


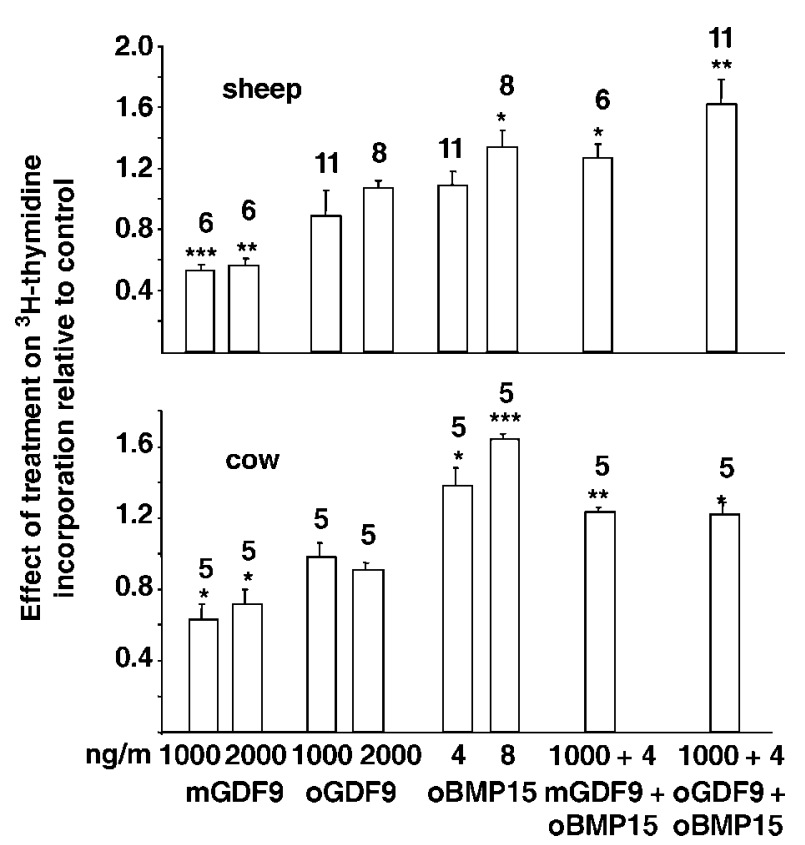

Figure 1 The effects of addition of murine $(\mathrm{m})$ or ovine (o) growth differentiation factor 9 (GDF9) and/or ovine bone morphogenetic protein 15 (oBMP15) on ${ }^{3} \mathrm{H}$-thymidine incorporation of ovine (top) or bovine (bottom) granulosa cells (numbers above each histogram refer to the numbers of independent pools of granulosa cells tested for sheep and cow respectively). Values represent means \pm S.E.M.

${ }^{*} P<0.05$ versus 293 conditioned media control, ${ }^{* *} P<0.01$ versus 293 conditioned media control, ${ }^{* * *} P<0.001$ versus 293 conditioned media control.

oGDF9 was held constant at $1000 \mathrm{ng} / \mathrm{ml}$ but oBMP15 diluted from $4 \mathrm{ng} / \mathrm{ml}$ to $0.04 \mathrm{ng} / \mathrm{ml}$, the significant stimulation of thymidine incorporation was only observed at the $4 \mathrm{ng} / \mathrm{ml}$ dose $(n=3$ independent pools of granulosa cells, data not shown).

\section{Progesterone production}

\section{Sheep}

mGDF9 stimulated progesterone production from ovine granulosa cells whereas oGDF9 was inhibitory. oBMP15 did not affect progesterone production on its own (Fig. 2). The addition of oBMP15 at $4 \mathrm{ng} / \mathrm{ml}$ did not alter or modify the affects of $1000 \mathrm{ng} / \mathrm{ml}$ of mGDF9 $(P=0.98)$ or oGDF9 $(P=0.92)$ when either were added alone (Fig. 2$)$. When oGDF9 was serially diluted from $1000 \mathrm{ng} / \mathrm{ml}$ to $10 \mathrm{ng} / \mathrm{ml}$ in the presence of $4 \mathrm{ng} / \mathrm{ml} \mathrm{BMP15}$, the significant suppressive effects on progesterone were observed at GDF9 concentrations $>200 \mathrm{ng} / \mathrm{ml}$ whereas when oGDF9 was held constant at $1000 \mathrm{ng} / \mathrm{ml}$, the significant suppressive effect was lost when BMP15 was diluted below $4 \mathrm{ng} / \mathrm{ml}(n=6$ independent pools of granulosa cells, data not shown).

\section{Cow}

mGDF9 did not effect progesterone production from bovine granulosa cells whereas oGDF9 inhibited production at 2000 but not $1000 \mathrm{ng} / \mathrm{ml}$ (Fig. 2). Addition of

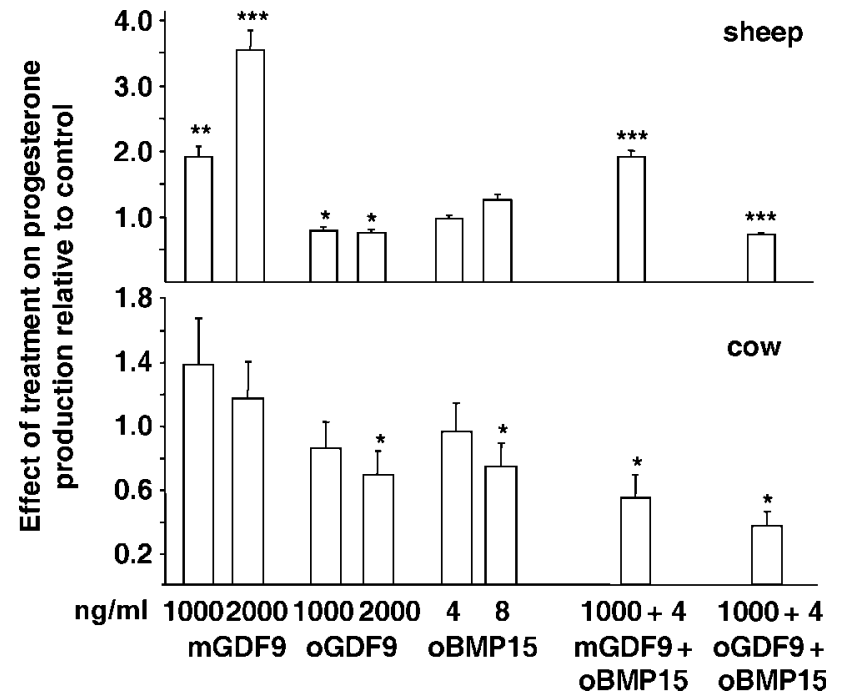

Figure 2 The effects of addition of murine $(\mathrm{m})$ or ovine $(\mathrm{o})$ growth differentiation factor 9 (GDF9) and/or ovine bone morphogenetic protein 15 (oBMP15) on progesterone production of ovine (top) or bovine (bottom) granulosa cells. For each treatment group in sheep, $n=6$ independent pools of granulosa cells tested except for the oGDF9 + oBMP15 treatment where $n=15$. For cows, $n=5$ independent pools of granulosa cells for all treatment groups. Values represent means \pm S.E.M. $* P<0.05$ versus 293 conditioned media control, $* * P<0.01$ versus 293 conditioned media control, $* * * P<0.001$ versus 293 conditioned media control.

oBMP15 at $8 \mathrm{ng} / \mathrm{ml}$ but not $4 \mathrm{ng} / \mathrm{ml}$ also inhibited progesterone production (Fig. 2). In contrast to the lack of effect observed with the low concentrations of either GDF9 or BMP15 alone, progesterone production was significantly suppressed when these two factors were added together. Dilution of either GDF9 from $1000 \mathrm{ng} / \mathrm{ml}$ or BMP15 from $4 \mathrm{ng} / \mathrm{ml}$ caused a loss in significant suppression of progesterone $(n=6$ independent pools of granulosa cells, data not shown).

\section{Inhibin production}

\section{Sheep}

mGDF9 inhibited whereas oGDF9 stimulated inhibin production (Fig. 3). oBMP15 did not affect inhibin production, although it appeared to block the inhibitory affects of mGDF9. There was no discernable co-operation between oGDF9 and oBMP15 (Fig. 3).

\section{Cow}

At the highest dose, mGDF9 inhibited, whereas neither oGDF9 nor oBMP15 affected inhibin production at any dose used. There appeared to be no co-operation between ovine GDF9 and BMP15 (Fig. 3).

\section{Discussion}

Consistent with previous reports, neither murine nor ovine GDF9 stimulated thymidine incorporation into ruminant 


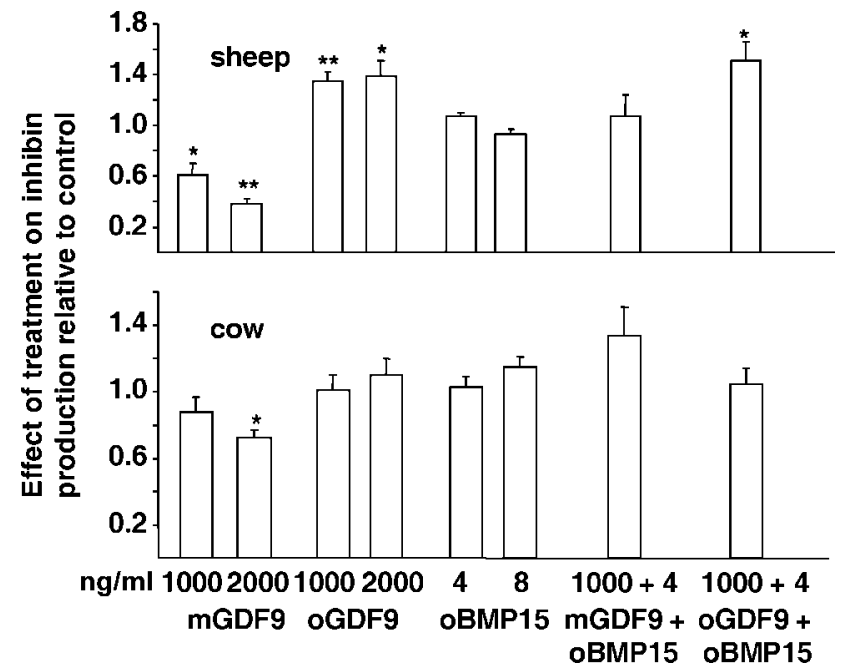

Figure 3 The effects of addition of murine $(\mathrm{m})$ or ovine (o) growth differentiation factor 9 (GDF9) and/or ovine bone morphogenetic protein 15 (oBMP15) on inhibin production of ovine (top) or bovine (bottom) granulosa cells. For each treatment, $n=6$ independent pools of granulosa cell tested for the sheep and cow. Values represent means \pm S.E.M. $* P<0.05$ versus 293 conditioned media control, ${ }^{* *} P<0.01$ versus 293 conditioned media control, ${ }^{* * *} P<0.001$ versus 293 conditioned media control.

granulosa cells (Nilsson and Skinner 2002). Indeed, in the present study, mGDF9 caused a small, but significant, suppression of thymidine incorporation in both ovine and bovine granulosa cells. This is in contrast to the stimulatory effect of mGDF9 on ${ }^{3} \mathrm{H}$-thymidine incorporation in rodent granulosa cells (Vitt et al. 2000, McNatty et al. 2005). This finding is consistent with the hypothesis that the function of GDF9 may vary between the species of origin of granulosa cells (Shimasaki et al. 2004).

In the present study, oBMP15 stimulated thymidine incorporation in ovine and bovine granulosa cells. This is consistent with the finding that hBMP15 stimulates thymidine incorporation in rat and human granulosa cells (Otsuka et al. 2000, Di Pasquale et al. 2004). However, using the same batch preparation as described herein, oBMP15 did not stimulate ${ }^{3} \mathrm{H}$-thymidine incorporation in rat granulosa cells (McNatty et al. 2005). These data are also consistent with the previously stated hypothesis for GDF9, that the functions of the BMP15 may vary between species of origin of granulosa cells. Moreover, the question as to whether this could, in part, be due to the species of origin of the growth factor is another variable that remains to be answered.

As we have reported for rat granulosa cells, a synergistic effect of GDF9 and BMP15 was observed with respect to thymidine incorporation in ovine granulosa cells, whereas in bovine cells the combined effects of ovine or murine GDF9 and oBMP15 were not different from those of BMP15 alone. Of interest was the finding that oBMP15 was able to neutralize the inhibitory effects of mGDF9 in bovine as well as in ovine granulosa cells. Taken together, these data support the hypothesis that GDF9 and BMP15 co-operate to regulate cell proliferation in granulosa cells. In general, the mean stimulatory effects of mGDF9+ oBMP15 or oGDF9 + oBMP15 on thymidine incorporation by ruminant granulosa cells were relatively small (i.e. 1.2-1.6-fold) compared with those observed in rats (6.5-7.0-fold; see McNatty et al. 2005). This, in part, might be related to the proliferation rates of granulosa cells in rodents and ruminants as assessed from the times taken for follicles to grow from the primordial/primary stages to ovulation (i.e. 20-35 days in rodents and 120170 days in ruminants; Peters and McNatty 1980, Driancourt et al. 1993, Hunter et al. 2004).

In ovine granulosa cells, mGDF9 stimulated, whereas oGDF9 inhibited, FSH-stimulated progesterone production. In bovine granulosa cells, mGDF9 had no effect, whereas the highest dose of oGDF9 was inhibitory. The inhibition of progesterone by oGDF9 was similar to the effects observed by Vitt et al. (2000) where rat GDF9 caused a dose-dependent decrease in FSH-stimulated progesterone production in rat granulosa cells from either diethyl stilbestrol (DES) or gonadotrophin treated animals and by Yamamoto et al. (2002) who showed that rat GDF9 caused a dose-dependent decrease in 8-bromo cAMP-stimulated production in human granulosa cells. However, the present results are in contrast to those by Elvin et al. (1999) and McNatty et al. (2005) who showed a lack of interaction between mGDF9 and FSH in regulating progesterone production by mouse and rat granulosa cells. Collectively these data suggest that GDF9 differentially affects granulosa cell function in different species. Moreover, it seems likely that the differential effects are related to both the species of origin of the granulosa cells and species of origin of the growth factor.

Compared with data for GDF9, there are relatively few reports on the effects of BMP15 with respect to steroid production in different species. In the present study BMP15 alone did not affect FSH-stimulated production by ovine granulosa cells but at the highest dose suppressed production by bovine cells. Previous studies report that hBMP15 suppressed FSH-stimulated progesterone production by rat granulosa cells (Otsuka et al. 2000). When ovine or murine GDF9 and oBMP15 were added together to bovine granulosa cells, progesterone production was suppressed to a greater level than that observed for either growth factor alone. Moreover, the suppressive effects of mGDF9 plus oBMP15 or oGDF9 plus oBMP15 were greater than additive indicating that these growth factors co-operate in bovine cells. This finding is similar to that found for GDF9 and BMP15 in regulating progesterone production in rat (McNatty et al. 2005). However, no such co-operative effect was observed between these growth factors in regulating progesterone production in ovine granulosa cells.

In previous studies evaluating the role of GDF9 on inhibin production, rat GDF9 stimulated granulosa cells from rats or humans (Hayashi et al. 1999, Roh et al. 2003, 
Kaivo-Oja et al. 2003), whereas no effects were observed with either murine or ovine GDF9 on rat granulosa cells (McNatty et al. 2005). In the present study, mGDF9 alone inhibited inhibin production from ovine and bovine granulosa cells, whereas oGDF9 increased inhibin production in ovine but not bovine granulosa cells. A large part of these differences may be attributable to the assays used to measure inhibin, the maturational stage of the granulosa cells and/or the culture conditions employed. However, it is important to note that mGDF9 and oGDF9 had opposite effects on inhibin production when tested side by side in the same pools of ovine granulosa cells. Thus, the species of origin of GDF9 may also account for some of the observed differences. Consistent with our previous data with rat granulosa cells (McNatty et al. 2005), oBMP15 did not appear to regulate inhibin production in either ovine or bovine granulosa cells. However, in contrast to the strong synergistic effects between GDF9 and BMP15 in regulating $\alpha$-inhibin production reported for the rat (McNatty et al. 2005), no co-operative effects were apparent for either ovine or bovine granulosa cells. Collectively, these data for inhibin show that the effects of GDF9 and BMP15 in vitro appear to be dependent upon the species of granulosa cells used for the assay and the species of origin of the growth factor. These suggest that species specificity of the growth factors may be regulated both at the target cell and by the structure of the growth factor itself. It is also possible that some of the differences observed in these studies are in part due to the different maturational states of the granulosa cells.

In sheep and cows, GDF9 mRNA and/or protein is present in oocytes of most, if not all, follicles at all stages of growth including primordial follicles (Bodensteiner et al. 1999). The present results are consistent with the notion that GDF9 alone may not be mitogenic in ruminant granulosa cells. It seems more likely, based on the in vitro evidence, that in sheep, but not cattle, GDF9 potentiates, in some way, the proliferative effects of BMP15 on granulosa cells. In sheep, BMP15 is present in oocytes of follicles from the primary stage onwards. Moreover, in sheep lacking active BMP15 (Galloway et al. 2000) or immunized against BMP15 or GDF9 (Juengel et al. 2002), follicular growth is arrested from the primary stage of development. The ontogeny of BMP15 expression in cattle is currently unknown. Nevertheless, the present in vitro findings are consistent with BMP15 alone being a key mitogenic factor during ovarian follicular development in ruminants.

In ruminants, BMPs are considered to be important luteinization inhibitors in granulosa cells during ovarian follicular development (Knight and Glister 2003, Monget et al. 2002). The present results for sheep suggest that GDF9 but not BMP15 is an important luteinization inhibitor, whereas for cattle both GDF9 and BMP15 contribute to suppressing progesterone.

Interestingly, while the effects of either of the growth factors alone were often divergent between species, the overall effects of both growth factors together in each species appear to be similar (current study and McNatty et al. 2005). These effects are indicative of a growth factor complex that stimulates cell proliferation and inhibits gonadotrophin-induced differentiation. An exception to this relates to the effects of mGDF9 with oBMP15 on progesterone production from ovine granulosa cells but this is unlikely to be physiologically relevant.

In conclusion, the effects of GDF9 and BMP15 in vitro appear dependent not only on the species of cell used for the assay, but also on the species of origin of the growth factor, indicating that the target cell and the structure of the growth factor itself both have an influence on the biological effects that were observed. These findings suggest some caution is needed when extrapolating findings from in vitro bioassays from one species to another. Given that GDF9 and BMP15 are likely to be present throughout most stages of follicular growth in sheep and cattle, it is suggested that these oocyte-secreted factors should be considered as an important functional signaling unit rather than as individual paracrine reagents acting independent of one another.

\section{Funding}

Supported by New Zealand Foundation for Research, Science and Technology, the Royal Society of New Zealand Marsden Fund, Ovita Limited, Dunedin, New Zealand and Sigrid Juselius Foundation.

\section{References}

Asher GW 1990 Effect of subcutaneous melatonin implants on the seasonal attainment of puberty in female red deer (Cervus elaphus). Animal Reproduction Science 22 145-159.

Bodensteiner KJ, Clay CM, Moeller CL \& Sawyer HR 1999 Molecular cloning of the ovine Growth/Differentiation factor-9 gene and expression of growth/differentiation factor-9 in ovine and bovine ovaries. Biology of Reproduction 60 381-386.

Davis GH, McEwan JC, Fennessy PF, Dodds KG \& Farquhar PA 1991 Evidence for the presence of a major gene influencing ovulation rate on the X chromosome of sheep. Biology of Reproduction $\mathbf{4 4}$ 620-624.

Di Pasquale E, Beck-Peccoz P \& Personi L 2004 Hypergonadotropic ovarian failure associated with an inherited mutation of human bone morphogenetic protein-15 (BMP15) gene. American Journal of Human Genetics 75 106-111.

Dong J, Albertini DF, Nishimori K, Kumar TR, Lu N \& Matzuk MM 1996 Growth differentiation factor-9 is required during early ovarian folliculogenesis. Nature $383531-535$.

Driancourt MA, Gougeon A, Royere D \& Thibault C 1993 Ovarian Function. In Reproduction in Mammals and Man, pp 281-306. Eds. C Thibault, MC Levasseur RHF Hunter, Paris: Ellipses.

Elvin JA, Yan C \& Matzuk MM 2000 Oocyte-expressed TGF-beta superfamily members in female fertility. Molecular and Cellular Endocrinology 159 1-5.

Elvin JA, Clark AT, Wang P, Wolfman NM \& Matzuk MM 1999 Paracrine actions of growth differentiation factor-9 in the mammalian ovary. Molecular Endocrinology 13 1035-1048.

Galloway SM, McNatty KP, Cambridge LM, Laitinen MP, Juengel JL, Jokiranta TS, McLaren RJ, Luiro K, Dodds KG, Montgomery GW, Beattie AE, Davis GH \& Ritvos O 2000 Mutations in an oocytederived growth factor gene (BMP15) cause increased ovulation 
rate and infertility in a dosage-sensitive manner. Nature Genetics 25 279-283.

Hanrahan JP, Gregan SM, Mulsant P, Mullen M, Davis GH, Powell R \& Galloway SM 2004 Mutations in the genes for oocyte-derived growth factors GDF9 and BMP15 are associated with both increased ovulation rate and sterility in Cambridge and Belclare sheep (Ovis aries). Biology of Reproduction 70 900-909.

Hayashi M, McGee EA, Min G, Klein C, Rose UM, van Duin M \& Hsueh AJ 1999 Recombinant growth differentiation factor-9 (GDF-9) enhances growth and differentiation of cultured early ovarian follicles. Endocrinology 140 1236-1244.

Hunter MG, Robinson RS, Mann GE \& Webb R 2004 Endocrine and paracrine control of follicular development and ovulation rate in farm species. Animal Reproduction Science 82-83 461-477.

Juengel JL, Hudson NL, Heath DA, Smith P, Reader KL, Lawrence SB, O'Connell AR, Laitinen MP, Cranfield M, Groome NP, Ritvos O \& McNatty KP 2002 Growth differentiation factor 9 and bone morphogenetic protein 15 are essential for ovarian follicular development in sheep. Biology of Reproduction 67 1777-1789.

Juengel JL, Hudson NL, Whiting L \& McNatty KP 2004 Effects of immunization against bone morphogenetic protein 15 and growth differentiation factor 9 on ovulation rate, fertilization, and pregnancy in ewes. Biology of Reproduction 70 557-561.

Kaivo-Oja N, Bondestam J, Kamarainen M, Koskimies J, Vitt U, Cranfield M, Vuojolainen K, Kallio JP, Olkkonen VM, Hayashi M, Moustakas A, Groome NP, ten Dijke P, Hsueh AJ \& Ritvos O 2003 Growth differentiation factor-9 induces Smad2 activation and inhibin B production in cultured human granulosa-luteal cells. Journal of Clinical Endocrinology and Metabolism 88 755-762.

Knight PG \& Glister C 2003 Local roles of TGF- $\beta$ superfamily members in the control of ovarian follicle development. Animal Reproduction Science 78 165-183.

McNatty KP, Heath DA, Hudson NL, Ball K \& Condell L 1992 Concentrations of immunoreactive inhibin in ovarian and peripheral venous plasma and follicular fluid of Booroola ewes that are homozygous carriers or non-carriers of the FecB gene. Journal of Reproduction and Fertility 95 489-502.

McNatty KP, Juengel JL, Wilson T, Galloway SM, Davis GH, Hudson NL, Moeller CL, Cranfield M, Reader KL, Laitinen MP, Groome NP, Sawyer HR \& Ritvos O 2003 Oocyte-derived growth factors and ovulation rate in sheep. Reproduction Supplement $\mathbf{6 1}$ 339-351.

McNatty KP, Juengel JL, Reader KL, Lun S, Myllymaa S, Lawrence SB, Western A, Meerasahib MF, Mottershead DG, Groome NP Ritvos O \& Laitinen MPE 2005 Bone morphogenetic protein 15 and growth differentiation factor 9 interact to regulate granulosa cell function. Reproduction 129 473-480.
Monget P, Fabre S, Mulsant P, Lecerf F, Elsen J-M, Mazerbourg S, Pisselet C \& Monniaux D 2002 Regulation of ovarian folliculogenesis by IGF and BMP system in domestic animals. Domestic Animal Endocrinology 23 139-154.

Nilsson EE \& Skinner MK 2002 Growth and differentiation factor-9 stimulates progression of early primary but not primordial rat ovarian follicle development. Biology of Reproduction $\mathbf{6 7}$ $1018-1024$

Otsuka F, Yao Z, Lee T, Yamamoto S, Erickson GF \& Shimasaki S 2000 Bone morphogenetic protein-15. Identification of target cells and biological functions. Journal of Biological Chemistry 275 39523-39528.

Peters H \& McNatty KP 1980 Follicle dynamics. In The Ovary, pp 113-116. Eds H Peters \& KP McNatty. London: Granada Press.

Robertson DM, Giacometti M, Foulds LM, Lahnstein J, Goss NH, Hearn MT \& de Kretser DM 1989 Isolation of inhibin alpha-subunit precursor proteins from bovine follicular fluid. Endocrinology $1252141-2149$.

Roh JS, Bondestam J, Mazerbourg S, Kaivo-Oja N, Groome N, Ritvos O \& Hsueh AJ 2003 Growth differentiation factor-9 stimulates inhibin production and activates smad2 in cultured rat granulosa cells. Endocrinology 144 172-178.

Shimasaki S, Moore RK, Otsuka F \& Erickson GF 2004 The bone morphogenetic protein system in mammalian reproduction. Endocrine Reviews 25 72-101.

Vitt UA, Hayashi M, Klein C \& Hsueh AJ 2000 Growth differentiation factor-9 stimulates proliferation but suppresses the follicle-stimulating hormone-induced differentiation of cultured granulosa cells from small antral and preovulatory rat follicles. Biology of Reproduction 62 370-377.

Yamamoto N, Christenson LK, McAllister JM \& Strauss JF III 2002 Growth differentiation factor- 9 inhibits $3^{\prime} 5^{\prime}$-adenosine monophosphate-stimulated steroidogenesis in human granulosa and theca cells. Journal of Clinical Endocrinology and Metabolism $\mathbf{8 7}$ $2849-2856$

Yan C, Wang P, DeMayo J, DeMayo FJ, Elvin JA, Carino C, Prasad SV, Skinner SS, Dunbar BS, Dube JL, Celeste AJ \& Matzuk MM 2001 Synergistic roles of bone morphogenetic protein 15 and growth differentiation factor 9 in ovarian function. Molecular Endocrinology 15 854-866.

Received 7 October 2004

First decision 12 November 2004

Accepted 17 December 2004 